\title{
Reading The Diary of Anne Frank: Historical-political Education as a Cross-sectional Task
}

\author{
Nico Weinmann
}

Before class starts, learning groups in their early adolescence are usually buzzing with boisterous laughter, wild chases, scuffles, passionate conversations about console games, fashion and music trends. As an integral part of this age-appropriate confusion, historical-political questions 'pop up' again and again: "Why was I insulted in the streetcar? Was it because of the color of my skin?", "Will the EU shut down Youtube?", "What is a concentration camp?", "Why is this summer so hot?", "Why do refugees want to come to Germany?" In all these questions there are problems that are important and instructive subjects for historical-political lessons. If they seem urgent, questions of this kind are likely to be addressed by teachers on an ad hoc basis at the expense of planned subject lessons. Often enough, however, students' questions are answered with: "You don't have any social science or history lessons this year. We're going to start with math."

With this everyday description, a fundamental practical problem of the implementation of historical-political school education is made obvious. ${ }^{1}$ It is considered one of the top learning goals (not only) in German schools. In the overwhelming majority of the federal states ${ }^{2}$, historicalpolitical education even has explicit constitutional status (Detjen, 2016). Along with religion, the social sciences are the only fields that are obliged to be taught. However, the constitutional mandate proves difficult to implement in everyday school life. This is mainly due to the fact that little time is allotted for politics and history lessons in the students' timetable. Historical and political education is far from accompanying students throughout their entire school career. ${ }^{3}$

1 The article will discuss this topic based on the case of Germany.

2 In the Federal Republic of Germany, the administration as well as the formulation of educational goals in schools and universities are essentially made at the state level by the federal Ministries of Education and Cultural Affairs.

3 A study by the University of Bielefeld has calculated for the content areas of civic education that German students in lower secondary schools (grades 5-10) have an 
It is therefore not possible to regularly arrange adequate learning opportunities, which is a particular loss for younger age groups, who are often curious and have a great desire to deal with historical-political issues. For this reason, didactics and political education initiatives have long called for educational reform initiatives to expand the teaching of social sciences in German schools (Albrecht et al., 2020). Teachers who want to conscientiously implement the historical-political constitutional mandate can hope for this educational offensive, however, if they want to do historical-political educational work in the here and now, they cannot afford to wait for it.

One current way of strengthening historical-political education in classroom practice is to more frequently open up historical and political learning paths beyond the actual history and social science lessons. From my perspective as a German teacher, I would like to contribute suggestions for the revival of historical-political education as the cross-sectional task of all school subjects. I will begin by outlining practical problems and the potential of historical-political education beyond history and political education. Thereafter I will describe a German lesson in which students are introduced to aspects of the national socialist dictatorship for the first time in school by reading The Diary of Anne Frank. To do this, I will address the learning situation of students in early adolescence as they encounter topics related to National Socialism, World War II, and the Holocaust. In the further course of the article, I will show that literary learning in German lessons does not have to suffer while the historical educational mission is being fulfilled. Conversely, the example even shows that simultaneous historical and literary learning can positively reinforce each other. I argue that a new self-understanding of historical-political education as a cross-sectional task of all school subjects should be based on 'synergetic learning arrangements'.

average of only one and a half years of 90-minute politics lessons per week during their school career until the end of compulsory education (Gökbudak \& Hedtke, 2019). Moreover, contrary to what the label of politics instruction suggests, the amount of political topics covered in this instructional time is small. It is only a little over one-third, whereas more instructional time is allotted especially for content areas in business administration and economics. A similar study on the proportion of historical education has yet to be conducted. The Association of Historians in Germany (VGD) has come to similar conclusions for the subject of history with regard to compulsory lessons (Droste \& Bongertmann, 2017). 


\section{Historical-political Education as a Cross-sectional Task}

In a joint declaration in 2018 , the federal state ministries of education and cultural affairs underlined that the historical-political educational mandate must be represented in the entire school day routine and, moreover, must be perceived in an interdisciplinary manner: "Strengthening young people in their commitment to the democratic constitutional state and their resolute stand against anti-democratic and anti-human attitudes and developments is the task of school and lesson development and the task of all subjects [...]" (KMK, 2018: 7, author's emphasis). The potential of cross-curricular historical-political educational work is obvious. For example, good math instruction is able to convey the persuasive power of evidence-based science. In the wake of the current corona pandemic, for example, math lessons could incorporate educational work against diverse conspiracy myths by examining statistics of incidence or hospital utilization. The corona pandemic also reveals the importance of science subjects for political education issues. For example, understanding and advocating for policy measures to combat the pandemic requires biological knowledge of the threat posed by the virus. Natural science lessons can also provide important approaches to the political issues of the future, such as the climate crisis or the ethical problems of new (bio)technologies. Religious education or ethics classes can help to raise fundamental ethical and moral issues in a democratic society, while any language class could teach key competencies of a democratic culture of debate and controversy along historical and political lines.

In theory, the concept of historical-political education that impacts all school subjects sounds coherent. In practice, however, it is accompanied by implementation challenges. Whether the historical-political education mandate is perceived outside of history and social science lessons and how depends in many cases on whether or not the teachers personally consider it important. There are no obligatory interdisciplinary curricula or generally applicable standards for social science content areas for the teaching of all subjects at German schools. The perception and also the quality of the interdisciplinary educational mission is therefore left to a large extent to chance. In addition, compulsory subject-specific performance and examination requirements take up so much space in everyday teaching that teachers often have the feeling that they simply do not have enough time for historical-political contextualization or problematization. Above all, linking the historical-political constitutional mandate to the concrete teaching practice of individual school subjects is inadequately dealt with in teacher training. At universities and in the second phase of teacher train- 
ing $^{4}$, didactics of history and politics are strongly attached to their own academic disciplines or to the original school subject of social science or history. Instructive incorporation of other school subjects is recommended but in everyday school life this is extensive and time-consuming. However, conceptualization of cross-curricular teaching always starts with teaching the actual historical-political subject (Mögling, 2010, Arand, 2017). In the relevant subject didactic handbooks and journals, there are hardly any lowthreshold and practical inter- or transdisciplinary incentives for historicalpolitical education in German, math or physics lessons. From the studies and practical teacher training, across the levels of school development, into the practice of teaching a subject in the classroom, there is a lack of self-evidence to live up to the constitutional mandate of historical-political education as a cross-cutting task of all subjects (similar: Overwien, 2020). With this article, I would like to contribute suggestions for the vitalization of historical-political education beyond history and political education. This will be done by providing insights into a lesson in which students in German classes deal with topics of the national socialist dictatorship for the first time in school.

\section{Memory Culture: A Challenge in Historical School Education}

German society is at the brink of a fundamental change in memory culture with regard to how the national socialist dictatorship, the Holocaust and the Second World War are being addressed. This impending upheaval can be understood as a "double generational change" (Assmann, 2013: 13). Part of this caesura is that the current generation of schoolchildren will no longer have any direct contact with witnesses of that historical period. Encounters with Holocaust survivors have "built an important bridge between history as personal experience and mere learning material" (ibid.). Meetings of this kind have always had the potential to make a far deeper impression on adolescents than, for example, commemorative ceremonies, schoolbooks, memorials, or media representation of remembrance culture. In addition, a generational change amongst the representatives of the German memory culture is taking place. Parts of the "68 gener-

4 In Germany, teachers go through two phases of education. The first phase takes place in universities. Here, teachers receive academic training and pass the first state examination. This is followed by a second phase of training, which prepares them primarily for teaching practice, where they pass their second state examination. 
ation" and the generation of war children contributed significantly to breaking away from the concealment of national socialist atrocities (German: "Schlussstrichmentalität") in the course of the 1960s. Confrontation of the crimes of the national socialist dictatorship was established as an integral part of the culture of remembrance in the Federal Republic. These generations are currently losing their interpretive sovereignty. In just a few years, they too will no longer be a vital part of the social memory of the German remembrance community (ibid.: $13 \mathrm{pp}$.).

In schools, this "double generation change" has already taken place. The fifth generation post national socialist dictatorship is sitting in classrooms today, taught by the third and fourth generations. Thus, incorporating aspects of National Socialism in historical-political school education is particularly important. At present, school contributes to the decision on which parts of historical contextual knowledge about the national socialist dictatorship and the Holocaust will be transferred across generational thresholds into the long-term cultural memory of German society and which parts will be forgotten. In general, school has the task of providing students with historical orientation through time and space. Children and adolescents should develop the competencies to participate independently and maturely in debates about the present and the future by using the power of historical argument (Brauch, 2015: 33, classic: Adorno, 1971). Awareness of and reflection on the national socialist dictatorship is important not only because it makes students knowledgeable about the past, sometimes providing them with arguments that justify their own political actions in the present, but also because it enables them to imagine historically-informed scenarios of how the world might develop in the future (general: Jordan, 2010: 17). German history between 1933 and 1945 can be regarded as a very brutal scenario - a materialized one. With the fall of the Weimar Republic, the national socialists' seizure of power, the Second World War, and the Holocaust, it becomes clear that democracy and the preservation of human rights are not guaranteed to last forever. In order for a democratic society to be robust and sustainable, it needs critical, curious citizens who are capable of dealing with conflicts in a peaceful manner. They should be capable of renewing and, if necessary, defending democratic order. School plays a prominent role in equipping the citizens of tomorrow with the necessary key competencies of historically informed, responsible political judgment and action. This acquisition of competencies is also relevant for the upcoming redefinition of the German culture of remembrance in its confrontation with the national socialist dictatorship. After all, today's students will decide how civil society initiatives will look in the future, how exhibitions will be curated, and how archives 
will be re-canonized. The extent to which scientific research will take place in the future and how films, books or blogs/vlogs of remembrance will be created is in their hands. In this way, the generation that is currently growing up will soon be wrestling with standards of the basic ethical and moral understanding of our democratic society and ultimately having to choreograph the self-evident aspects of historical-political memory anew.

\section{The learning situation: Dealing with the national socialist dictatorship}

Against this backdrop, the education ministries of the German states agree that students must learn about aspects of the national socialist dictatorship in school. A recent study by the Scientific Service of the German Bundestag (Deutscher Bundestag, 2018) outlined at what point in the curriculum and to what extent this is currently being done. Normally, the aforementioned subject areas are included in 9th or 10th grade history lessons, thus only at the end of general compulsory education. There are various reasons for dealing with National Socialism, World War II, or the Holocaust at this point in the school career. The majority of history curricula proceeds chronologically. History lessons begin in antiquity and end in contemporary history. It is therefore often for pragmatic reasons that the study of National Socialism is scheduled for the end of the curriculum. In addition, there is a widespread assumption in historicalpolitical didactics that confronting 'big and difficult' topics should only be expected of older children and adolescents. This assumption is based on cognitive psychology: Young people are only cognitively capable of differentiated and complex judgments at a certain age (e.g. Grammes \& Welniak, 2008). This curricular pragmatism and the cognitive-psychological assumption are contrary to the interests and motivations of children and adolescents. My own teaching experience shows that children and adolescents on the verge of becoming adults have a pronounced desire to explore large and 'adult' historical and political problems. The curricula of historical-political education regularly miss this 'window of opportunity' in early adolescence by not attributing adolescents the maturity to deal with 'adult' topics. This also affects questions about the national socialist dictatorship, which are already an integral part of adolescents' thoughts and conversations at an age before the topic is scheduled in school. My personal impressions can be generally substantiated by an empirical survey done by the Forsa Institute, according to which the majority of adolescents in the said age group were rated as being between rather and greatly interested in historical topics (Forsa, 2017). The aforementioned report of 
the Scientific Service of the German Bundestag also problematizes the late thematization of National Socialism in schools. In the spirit of including historical-political education in all subjects, the authors suggest that other subjects should create access to this topic before it becomes compulsory in history lessons. This applies in particular to German lessons (Deutscher Bundestag, 2018: 7).

When teachers of German undertake the task of dealing with the national socialist dictatorship or the Holocaust in their lessons, they are regularly confronted with didactic treatises in which they are warned of a particularly challenging learning situation. Thus, "resistance" and "defensive attitudes" on the students' part are to be expected (Wrobel \& von Brand, 2012: 4). Learners may often "block" or "refuse". For example, the "time gap is too great" for them to comprehend the necessity of an intensive examination of National Socialism. Another challenge is that children and adolescents with migration experience lack the family connection to the German past as an important form of access to the subject area (ibid.). Learning obstacles of the kind mentioned certainly occur among the current generation of students. It also makes sense to anticipate difficulties in the learning situation from a didactic point of view in order to take them into account in lesson planning. However, it is noticeable that - as in the case cited - the subject didactic processing of student motivation while dealing with aspects of National Socialism in German lessons is often limited to problems in a one-sided way. From the teacher's perspective, reading these didactic treatises is demotivating as they give the impression that an extremely arduous course of instruction lies ahead.

Dealing with students' desire and unwillingness to engage in lessons is part of the daily bread in the teaching profession. This is not a unique feature of the subject areas of the national socialist dictatorship. Just as at the beginning of each teaching unit, open-ended learning status diagnoses should take place here as well, which inquire about motivational situations in order to arrange learning that is tailored to fit and close to the students (Scholz, 2014). My own evaluation of students' motivation in the run-up to discussing The Diary of Anne Frank in German lessons contradicts the often used image of students who are unwilling to learn. I have not had the impression that the unwillingness to deal with this topic is causally related to temporal or migration-related distance from the subject matter. In the context of my learning level diagnoses, students whose family roots lie in Germany indicate that they have a great interest in tracing their own, often unknown, family history. Jewish children report on antisemitic everyday experiences, which they can address throughout the lesson. Children and adolescents with a migration background have 
the opportunity to address their own experiences of discrimination and racism in Germany when they deal with the topic of National Socialism. Some of these students have also had very direct experiences with war, dictatorships, political persecution, expulsion and flight. It is often motivating for them to participate in a lesson in which they can relate their own experiences to historical events in the country where they are currently growing up. In general, however, my students state in advance that they are looking forward to "finally being able to deal with an important and serious topic" (student quote) in German class. They feel taken seriously when they are trusted with this 'adult' topic in school. These impressions correspond more to the image in the empirical survey done by the Forsa Institute of adolescents who are interested in history for the first time (Forsa, 2017). However, these motivational situations are not synonymous with a great wealth of knowledge. In Germany, for example, only 59 percent of students over (!) 14 years of age know that Auschwitz-Birkenau was a Nazi concentration and extermination camp during World War II (ibid.). ${ }^{5}$ My students also have little historical contextual knowledge about National Socialism prior to this series of lessons. They often reduce the national socialist rule down to Hitler and tend towards simple, black-andwhite moral schemes ("Nazis against Jews"). ${ }^{6}$ If first contact with National Socialism is established at school, the lesson planning should cater for a learning group of adolescents with diverse motivational situations and low-level prior historical knowledge. In this regard, The Diary of Anne Frank is particularly suitable as a learning object.

\section{The Diary of Anne Frank in German Lessons}

This diary has long been one of the most widely read set works in Germany. There is a flood of handouts and teaching materials on its use in

5 The exact validity of studies of this kind can certainly be doubted if generalized conclusions are drawn about historical contextual knowledge on the basis of knowledge queries. I understand the findings rather as a tendency, which corresponds to my diagnosis of the learning situation.

6 These explanatory figures of my learning level diagnoses thus largely correspond to the results of a study by Meik Zülsdorf-Kersting, who compared current surveys with findings from the 1960s and 1980s under the title "Youth and the Holocaust" (Zülsdorf-Kersting, 2007). Throughout time, young people tended to "Hitlerize" the historical context of the national socialist dictatorship and to adopt morally simplistic black-and-white schemes. 
German lessons (e.g. Diekhans, 2003). In addition to the relevant textbook publishers, numerous civil society organizations offer learning materials. ${ }^{7}$ They all emphasize the didactic potential of The Diary of Anne Frank in school lessons. In the following remarks, I will concentrate on the aspect that it is a particularly useful object for simultaneous literary and historical learning. I will elaborate on this idea on the basis of the peculiarity that this diary crosses between text types. It is a historical source or, more precisely, the self-witness ("ego-document") (Schulze, 1996) of a witness of that period. At the same time, it is world literature by a young female writer (Pressler, 2013). Characteristics of both types of texts are already inherent in the genesis of the work. Anne Frank wrote diaries from June 12, 1942 to August 1, 1944. In her notes, she offers deep insights into the world of thoughts and feelings of a young girl who spends her formative adolescent years hiding in a space of just a few square meters. She thus vividly documents the persecution of the Jews during the national socialist dictatorship. Until the spring of 1944, she wrote the diary only for herself. However, she changed her mind after listening to the radio and hearing the Dutch Minister of Education, who was in London in exile, talk about publishing diaries that dealt with the suffering of the Dutch during German occupation as soon as the war was over. She decided she would publish a book after the war, for which her diary would provide the basis. From then on, Anne Frank began to rewrite her notes for a broader audience. She shortened, supplemented, gave her housemates new identities, and was inspired by literary models of her time. As a result, four editions of the diary coexist today, each with a stronger emphasis on either the personal or the literary segments intended for publication (ibid.: $11 \mathrm{pp}$.$) .$

Based on the ambiguity of the diary as a text type - as a personal document of a time witness and as a literary work - the basic potential of a course of instruction can be outlined, which simultaneously paves historical learning paths in German lessons out of an arrangement of literary learning. In the following section, I will show that literary and historical learning do not compete with each other, nor do they simply complement each other. Rather, they can mutually reinforce each other: Literary learning competencies are more profoundly initiated by supplying simultaneous historical learning input while German teaching methods conversely enable historical learning. An essential prerequisite for success

7 The city of Amsterdam should certainly be highlighted here. The city provides a rich digital educational offering, https:/www.annefrank.org. 
is that German lessons not only make use of the special literary quality of the diary, they also systematically integrate its characteristics as a contemporary witness document into the lessons. In doing so, German teachers should orient themselves on the didactic principles of history teaching in order to arrange a synergy between literary and historical learning.

\section{Literary Learning with The Diary of Anne Frank}

One of the main reasons for the recurring use of The Diary of Anne Frank in German classes lies in the literary quality of particular closeness. As an author, Anne Frank had a remarkable ability to speak and write, which she uses to create a strong closeness to the reader. This already happens through the form of her diary. She addresses her entries to 'Kitty', a fictitious pen pal. Her recurring form of address and letter - "Dear Kitty..." - invites the reader to assume the role of the pen pal throughout. In this way, the diary offers the reader a constant dialogue with an adolescent and a writer. Readers are invited to answer Anne Frank, to ask her questions, to confirm or contradict what she says. Above all, however, Anne Frank presents the most intimate type of text imaginable in the form of a diary through which she provides deep insights into the world of thoughts and feelings of an adolescent. In doing so, she deals with content that makes thinking and feeling empathetically possible, especially among those of her age - even 75 years after the diary was written. For example, Anne repeatedly argues with her parents and the people living in the back of the house. She lives out her anger, reports deep grievances, and expresses forgiveness. In this way, the author not only shows early adolescent readers her own culture of debate, she caricatures how adolescents sometimes still argue and sulk in adulthood. In many other places, Anne Frank shares with her readers the timeless experience of growing up. In the course of time, for example, she falls in love with Peter, a roommate at the back of the house. She plays the 'game of first love' from close and afar, from first kiss to first disappointment, from infatuation to rationalization, resembling the rules of a love game that people of the same age still play today when they lose their hearts for the first time while reading Anne Frank's diary. Last but not least, Anne dreams the dreams of young people who still have their lives ahead of them right up to the end of her notes. She harbors the desire to become a writer without anticipating the cruel end of her dream: At the moment of her recording, she is in the process of creating world literature without ever being able to experience the fulfillment of her dreams. The abrupt end of the diary allows the reader 
to participate in the story of an adolescent whose dreams of life, love of life, humor and infatuation are extinguished along with her life in the concentration camp of Bergen-Belsen. With her diary, Anne Frank gives the anonymous number of many millions of victims a tangible face and an accessible voice decades after the Holocaust.

The literary quality of proximity holds the potential to initiate certain competencies of literary learning in a special way. First of all, this concerns the ability to unfold imaginative sensual perceptions from reading a literary text (Spinner, 2006: 8). Reading literature requires the basic competence of assuming the "role of a director" for whom the literary text serves as the script of a film. Practiced readers succeed in bringing what they have read to life on the basis of their own imagination, in their mind's eye like a film (ibid.). German lessons want to create learning opportunities to develop this competence. The diary presents an ideal tool for this project because Anne Frank awakens the senses linguistically when she attempts, passage after passage, almost pedantically to describe the life and routine in hiding without leaving anything out. The reader sees, hears, smells and feels with her the life in the annex.

Furthermore, reading can be used to train "involved reading" (Spinner, 2006: 8p.) in a special way. Anne Frank keeps holding up a literary mirror for the reader by dealing with the timeless everyday questions of an adolescent: Looking into it presents an opportunity for identification. While reading, one sees oneself and one's own life-world experiences. The view can also be unsettling. Through confrontation with the otherness of the fates, experiences, feelings or ways in which Anne Frank and the other protagonists act as part of a group of Jewish persecutees, the diary simultaneously makes experiences of alterity and difference possible. Literary learning then transcends the process level of text comprehension and necessitates readers to develop the willingness to invest existing knowledge, emotional engagement, and self-reflection in reading processes by linking what they read back to their own experiences and life-world and, based on the reading experience, begin to reflect on themselves (Rosenbrock \& Nix, 2017). Such reading experiences of identification, alterity/difference, and self-reflection ultimately enable moments of literary follow-up communication as exchange and debate about the literary experience in German class, but also with peers or family after actual class time. Thus, the literary experience enters the realm of social interaction.

In order to develop these competencies at a literary learning level, reception-aesthetically inspired action-and-production oriented methods play a key role (Spinner, 2011). In this case, the reader in the role of co-author is placed at the center of the learning arrangement. Action-and-production 
oriented German language teaching acknowledges that literature sometimes has ambiguous voids of meaning formation, which mature readers plausibly fill with meaning that is fed by their own worlds, imagined and existing. Teaching literature aims to enable processes of meaning construction, for example, by having students add to passages in the text, rewrite them or transfer them into other media formats (Spinner, 2006: 9). The Diary of Anne Frank offers a number of opportunities for this. For example, the author mentions dialogues that were not written down in the diary itself, such as when Anne Frank's sister, Margot, tells her that the Gestapo wants to arrest her. Anne Frank also refers to conversations of this kind when debating war events at the dinner table in the annex and arguing about everyday life in hiding or when Peter and Anne exchange ideas about their relationship after their time in hiding. In their role as coauthors, students can fill in these missing dialogues, act them out or film them. Comparing the different versions then creates further opportunities for communication.

Following action-and-production oriented procedures, students can, for example, be confronted with "cultural patterns of feeling" (Ulrich \& Ulrich, 1994) that tie in with their power of imagination and world of experience through tasks such as: You have reflected on the relationship between Anne and her mother. In comparison to Anne, what is love between parents and their children for you? Other models of feeling might be: What does friendship, fear of death, the loss of a loved one or imprisonment feel like? German lessons can also address students' "moral judgment" based on the diary (Spinner, 2001): "Anne calls the helpers "heroes". What is a hero to you? Do you think that the helpers of the people in the secret annex were heroes? Would you have helped the people in hiding?". As illustrated, literature classes can take advantage of the diary's proximity in language, form, and content and open learning paths to develop sensory perceptual power among students, encourage involved reading, stimulate experiences of identification and difference/age, initiate processes of self-reflection, and provide opportunities for literary follow-up communication that links to cultural patterns of feeling and moral judgment.

\section{Synergies of Historical and Literary Learning with The Diary of Anne Frank}

In addition to these learning opportunities, this diary offers further didactic potential as a historical contemporary witness document. Literature always consists of a weave of fiction and reality. In The Diary of Anne Frank, the elements of reality are more tangible than in conventional 
fiction. The author regularly and explicitly refers to past reality in her notes. As a contemporary witness document, her individual narrative is consistently linked to historical macro events. When readers without a pronounced historical background encounter such links, they are inevitably confronted with the limits of their ability to make sense of them. They lack knowledge of historical contexts that cannot be filled with meaning simply by drawing on their own experiences and lifeworld. In a lively classroom atmosphere, the limits of meaning construction are usually expressed in comprehension questions put forward by the students. Examples of this are: Why were Anne and her family persecuted? Why were the people living in the secret annex helped even though it was so dangerous? Who did the people living in hiding have to fear and who betrayed them? Why did the annex residents hope for an Allied victory? What happened to Anne, other Jews and victims of the Holocaust in Auschwitz? etc. Didactic manuals for teaching German tend to anticipate student questions of this kind. Common teaching models include basal textbook texts, timelines, or references to documentaries that summarize historical background information in a condensed form (e.g. Fenske, Schurf \& Wagner, 2011). This is based on the well-intended thinking around wanting to contribute towards the prereading plan for the students. The students should be prevented from crossing their limits of meaning construction, so that the actual agenda of literary learning is not lost sight of. I argue that this common practice contributes both to missing out on opportunities for historical learning and leaving untapped potential within literary learning.

In place of the prereading plan, I propose a problem oriented and problem-solving approach in German lessons, which would normally be the starting point of competence-oriented history lessons in teaching models (Hensel-Grobe, 2017). A history lesson of this kind takes up students' questions, reformulates them into "historical guiding questions" (Thünemann, 2013: 146), the investigative and exploratory clarification of which supports and drives the instruction during the course of the lesson. Such a procedure can certainly be integrated into arrangements of literary learning, which can be illustrated using early passages of the diary.

At the beginning of her diary, Anne Frank vividly recounts the tightening of Jewish policy in the Netherlands, the obligation to wear the Jewish star, the ban on driving, the restriction of shopping to certain times, a curfew, the compulsion only to go to Jewish hairdressers or schools, or the prohibition on engaging in leisure activities. When the Nazis began deportations in Holland as well, Anne Frank and her family were eventually forced to flee to the hiding place at the back of her father's factory. At this point, German lessons can take up Anne Frank's narrative of the 
tightening of racial laws under the national socialist dictatorship. The subject of the lesson sequence becomes the leading historical question of why and in what ways Jews like Anne were persecuted by Nazis. Dealing with this question makes it necessary to reconstruct the story of Anne Frank historically. In this endeavor, German lessons can adopt moments of the history didactic principle of "multiperspectivity" (Lücke, 2017). This is based on the assumption that history is always told and judged from different perspectives. Historical learning aims to develop the students' ability to understand and judge such multi-perspective views on history independently.

Anne Frank's descriptions of the intensification of racial policy can be complemented by the perpetrator's perspective in order to make the national socialist crimes comprehensible "as cases in history of human deeds" in the sense of a "Holocaust education", which were not perpetrated by "demonic bloodthirsty maniacs" (Mounajed, 2017: 287). In this sense, the systematics of discrimination, isolation, deprivation of rights, torment, and the eventual extermination of Jews from 1933 onwards can be elaborated on beyond contextual knowledge with the use of examples. It makes sense to focus on one of the peaks of the intensification of national socialist racial policy in order to relate it to the story of Anne Frank. This could be the Nuremberg Laws (1935), the November pogroms (1938), the introduction of the Jewish star (1941) or the Wannsee Conference (1941), in which the extermination of the Jews was decided and coordinated. The historical learning path can then make use of further moments of the multi-perspective principle. Anne Frank describes her everyday life before going into hiding - as a student at a Jewish school and as a teenager who experiences torment and discrimination by racial politics. This perspective can be contrasted with the everyday life of other young people of her time. Thus, a learning assignment might be: Write a diary entry from the perspective of a student at your school during the time of the national socialist dictatorship. Explore what everyday life was like at your school in Anne Frank's time. School archives often house instructive contemporary documents that can be used for the learning task. Anne Frank's documentation can not only be compared with everyday experiences of her time but dealing with it also creates the opportunity to compare the everyday life of that time with the life of today's students, keeping the present and living environment in mind (Lücke, 2017).

Numerous other opportunities for creating a lesson topic by linking the narrative of the individual with macro events in history present themselves throughout the diary in the manner described. For example, Anne writes large parts of the diary as a member of a community of hiders. At this 
point in the diary, German lessons can show the possibilities and limits of escaping persecution by fleeing into exile or going into hiding through comparisons of the lives of the people living in the secret annex with descriptions of the fates of others persecuted under National Socialism. Later, Anne Frank reports from the annex about the mortal fear of being discovered, about the promise of defeating the Nazis in the war as being the annex residents' only chance of survival, about hope-inciting English radio reports on Italy's surrender or the Allied landings in Normandy. At the same time, she writes of traumatizing bomb-filled nights. At these points, the diary makes it possible to reconstruct Anne Frank's perspective on the events of the war. The diary also tells the story of helpers who put their own lives in danger in order to save those in the secret annex. Mirroring the story of the helpers, Anne Frank documents the collaboration in the Netherlands with the Nazis and the spread of antisemitism among Dutch people as well. The diary shows that even under Nazi rule there were opportunities for personal decision making and chances to take different courses of action, resisting or collaborating, which can be used to explore the question of guilt in depth.

If German lessons succeed in reconstructing the individual narration of Anne Frank within the events of macro-history and/or in comparing it with other perspectives of her time, historical learning paths will be taken that also benefit the return on literary learning. By answering leading historical questions, the students work out how macro-historical puzzle pieces such as the intensification of racial politics, the war, deportation, the Holocaust, forms of resistance or collaboration fit into the individual narrative of the diary and Anne Frank's fate. This way students can experience that, for Anne Frank as well as for other contemporaries, one's own life is attached to institutions, structures, policies, and events of general historical significance (Brauch, 2016: 13). Moreover, in the diary, in addition to the inhabitants of the annex, such as the helpers or the collaborating Dutch, Hitler and "the Jews" are joined by other groups of people who went their specific way through the period of the early 1940s. When students independently explore and reflect on this via historical learning paths, it also benefits the development of their competency in literary learning. Their literary meaning construction is then not only linked to individual imagination and personal experience but also to new historical knowledge, which in turn helps to compensate for the gaps in the diary and its lack of closure. In this way, students develop literary skills that will also help them in later readings. The historical learning paths enable them to decipher the diary's web of fiction and historical reality independently. This also offers new opportunities for follow-up communication as, during the 
course of reading, the students are enabled to judge and reflect on the historical content, beyond cultural patterns of feeling and morality. The individual narrative of Anne Frank is cause for the evaluation of morality, attitude, responsibility and guilt during the national socialist dictatorship. German lessons then simultaneously initiate moments of competence in historical orientation and judgment in an arrangement of literary learning (Becker, 2017). Overall, this synergetic interweaving of literary and historical learning makes a more complex literary experience possible in German lessons than if the paths of historical learning are abbreviated by fleeting prereading plans. In teaching practice, the historical learning paths should be integrated into complex, problem-solving learning tasks or the creation of large learning products of literary learning, as is customary in contemporary and competence-oriented literature teaching (Köster, 2016). For example, they can be task components of reading portfolios/diaries or can be integrated into the production of podcasts, video clips, theater productions, or exhibitions.

\section{Showing the Unshowable?}

In the above explanations, the focus was on the aspect of how literature lessons can benefit from historical learning paths. Furthermore, a final in-depth look at the lesson shows how a subject-specific contribution of German lessons to historical-political education can look. With an abrupt end to the diary entries, students inevitably ask the question: What happened to Anne Frank and the people living in the secret annex? Linked to this is the thematization of the deportation and murder of over six million people in the concentration and extermination camps under national socialist dictatorship. Dealing with the Holocaust in the school classroom is fundamentally extremely emotionally challenging for both teachers and learners (Mounajed, 2017: 266). It is difficult to deal appropriately with the mass extermination of human beings within the frame of physical education and math classes. For good reasons, learning about the Holocaust therefore often takes place at extracurricular learning sites over the course of full-day or multi-day excursions. If the subject is dealt with in class, children and teenagers should not be left alone with their emotions. The lesson design should be situationally flexible in order to relieve emotions, to reflect on them and, if necessary, to adapt lesson plans in consultation with the students (ibid.).

One possibility for dealing with the Holocaust in the context of the lesson is to deal with the literary adaptation of the diary by director Hans 
Steinbichler released in 2016. The film is a useful learning tool for German lessons. In principle, working with it enables a comparison between the students' imaginative conception and Steinbichler's film adaptation and fictionalization. In dealing with the film adaptation, it becomes clear that Steinbichler has chosen to tell Anne Frank's story beyond the notes of the diary by tracing the deportation and arrival at Auschwitz in two final scenes. During the deportation, Anne gazes into the camera in an extreme close-up shot. Shadows cast around her eyes suggest a crack of light in a freight car. Like a diary entry, she reports on the horrible conditions in the wagon and on her fear and despair in the face of approaching death. In this deportation scene, the view exceeds Anne Frank's boundaries of intimacy and uses the medium of film to establish closeness in the conceivably brutal moment of impending death (Haag, 2016). The following scene shows the arrival of Anne Frank, her mother, and her sister in Auschwitz as they are tattooed with prisoner numbers and have their hair shaved off. The tattooing and the violently exposed scalp are symbolic of the excessive degradation and dehumanization in the camp (ibid.). This fictionalization of Anne Frank's development through the cinematic tools of visual language and alienation make it possible to address the Holocaust during class time as well. Since both scenes refrain from the direct depiction of violence, mountains of corpses, gassing and crematoria, it is left to the imagination, emotional readiness and cognitive development of the individual students which images are evoked and which feelings are set in motion. At this point, fictionality provides emotional relief.

Furthermore, German lessons are able to problematize the cinematic representation of the deportation and the arrival in Auschwitz. For as long as there have been films about the Holocaust, filmmakers, critics, and above all Holocaust survivors have debated the ethically justifiable and culturally appropriate aesthetics of the depiction of industrial mass murder (for more details, see Schultz, 2012). Students can be familiarized with the different positions within this debate and find answers to the controversies in class in conjunction with the literary adaptation of the diary: Is Auschwitz unrepresentable? Can the traumatic experiences of the survivors be conveyed on film at all? What forms of representation would have been alternatives to Steinbichler's realization? Does omitting the extreme violence of mass extermination amount to trivialization? Conversely, does showing depictions of violence run the risk of putting viewers in a voyeuristic perspective, scaring them off, or even triggering a habituation effect? Students can evaluate and discuss questions of this kind by taking on the role of film critics with which they are partly familiar (Petrik, 2016). This way of problematizing the fictionalization of the Holocaust also presents the opportunity to bring indi- 
viduals' emotions into the classroom and to reflect on them when students share what moved them emotionally about Steinbichler's filmic portrayal. That way, it is not only competency in film analysis that is initiated by addressing the aesthetic effect of camera angles and perspectives, visual language and alienation. Historical-political judgment skills develop at the same time as students learn to evaluate the difficulties of fictionalizing the Holocaust according to ethical-moral standards. Thus, German lessons provide them with the capacity for historical-political action, which is particularly important for the generation currently growing up. The students practice the skill of discussing ethically and morally appropriate medialization, sometimes also fictionalization of the memory of the Holocaust. The critical examination of this adaptation of literature for screen thus becomes a way of assessing action alternatives hypothetically, thus being part of the memory culture of the future without having been a contemporary witness.

\section{Synergetic Learning Arrangements as Part of a Strengthening of Historical- political School Education}

Using examples, my insights into the course of instruction have shown that the learning outcome of subject instruction can benefit from the integration of historical-political learning paths. Synergetic learning arrangements of the kind described can help to make historical-political school education more immediate as a cross-sectional task of all subjects. In the future, this will require a change in thinking at many levels of school life: Teachers should explore how historical-political learning paths can be integrated into the curricula of their lessons. At the level of school development, individual initiatives of this kind can lead to interdisciplinary curricula or generally applicable standards for social science content areas for the teaching of all subjects. Most importantly, rethinking subject didactics at universities and the second phase of teacher training is needed. ${ }^{8}$ So far, the chairs of history and political didactics as well as the teacher training colleges have not provided enough impetus to perceive historicalpolitical education as a cross-sectional task beyond the boundaries of the subjects. Interdisciplinary exchange at specialist conferences and in subject didactic publications would be necessary. This would provide the basis for interdisciplinary or interconnecting teacher training programmes or

8 See footnote 3 . 
practical teaching materials - in the sense of historical-political education in German, maths or biology lessons.

However, if the constitutional mandate of historical-political education is to be implemented in schools on a permanent, reliable basis and in accordance with robust quality standards, fundamental changes are required. The small number of weekly hours that is allocated to the study of social science and history by the educational policy and school system administrative control is evidence of the relatively low value placed on democracy education. The constitutional mandate thus remains a well-intended appeal that repeatedly puts teachers in the position of having to confront practical problems and challenges regarding its conscientious implementation. In the long run, there is no way around a reform initiative to expand the number of weekly hours of social studies. At a few schools, mostly in comprehensive schools with a model character, it has now been proven for decades that the combination of social science subjects (history, politics, geography) is taught throughout - with main subject status and a weekly share of up to four hours. If historical and political education were given the same space as the humanities and mathematics/science subjects, this would not only create more learning time. After all, timetables are the 'hard currency' of the education system. Various financial flows from the education budget depend on them. This affects not only the funding of new teaching positions but also that of study places, professorships and staff at universities, as well as teacher training. Strengthening the subject teaching would benefit the qualification and professionalization of historical-political school education as a whole, both in its perception as a cross-sectional task of all subjects and in the socio-scientific subject network.

\section{Literature}

Adorno, Theodor W. (1971): Erziehung zur Mündigkeit, Suhrkamp: Frankfurt.

Albrecht, Achim, Bade, Gesine, Eis, Andreas, Jakubczyk, Uwe \& Overwien, Bernd (2020): Jetzt erst recht: Politische Bildung! Bestandsaufnahme und bildungspolitische Forderungen. In: ibid. (Eds.): Jetzt erst recht: Politische Bildung! Bestandsaufnahme und bildungspolitische Forderungen, Wochenschau Verlag: Frankfurt a.M., 7-26.

Arand, Tobias (2017): Fächerverbindender Geschichtsunterricht. In: Barricelli, Michele \& Lücke, Martin (Eds.): Praxis des Geschichtsunterrichts 2. Wochenschau Verlag: Wiesbaden, 308-339.

Assmann, Aleida (2013): Das neue Unbehagen an der Erinnerungskultur. Eine Intervention, München: C H Beck. 
Brauch, Nicola (2016): Das Anne Frank Tagebuch. Eine Quelle historischen Lernens in Unterricht und Studium. Kohlhammer: Stuttgart.

Brauch, Nicola (2015): Geschichtsdidaktik. Oldenbourg: De Gruyter.

Detjen, Joachim (2016): Politische Bildung. Bildungsaufgabe und Schulfach. In: https:/www.bpb.de/gesellschaft/bildung/politische-bildung/193595/bildungsauf gabe-und-schulfach? $\mathrm{p}=0$.

Deutscher Bundestag (2018): Die Verankerung des Themas Nationalsozialismus im Schulunterricht in Deutschland, Österreich, Polen und Frankreich, Aktenzeichen: WD 8 - 3000 - 091/18. Berlin: Deutscher Bundestag.

Dieckhans, Johannes (2003): Das Tagebuch der Anne Frank. Einfach Deutsch. Unterrichtsmodell. Braunschweig: Schöningh Westermann.

Fenske, Ute, Schurf, Bernd, \& Wagener, Andrea (2011): Tagebuch - Anne Frank. Deutschbuch - Kopiervorlagen. Berlin: Cornelsen Verlag.

Forsa (2017): Geschichtsunterricht, forsa Politik und Sozialforschung GmbH: Berlin. https://www.koerber-stiftung.de/fileadmin/user_upload/koerber-stift ung/redaktion/handlungsfeld_internationale-verstaendigung/pdf/2017/Ergebnis se_forsa-Umfrage_Geschichtsunterricht_Koerber-Stiftung.pdf.

Gökbudak, Mahir \& Hedtke, Reinhold (2019): Ranking Politische Bildung 2018. Politische Bildung an allgemeinbildenden Schulen der Sekundarstufe I im Bundesvergleich. Working Paper N ${ }^{\circ}$ 9. Bielefeld: Universität Bielefeld, Didaktik der Sozialwissenschaften.

Grammes, Tilman \& Welniak, Christian (2008): Diagnostische Kompetenz. Der Beitrag der kognitiven Entwicklungspsychologie - ein Überblick. In: Weißeno, Georg (Ed.): Politikkompetenz. Was Unterricht zu leisten hat. Bonn: Bundeszentrale für politische Bildung, 331-346.

Haag, Stella Donata (2016): Filmbesprechung. Das Tagebuch der Anne Frank. In: kinofenster.de, Film des Monats 03/2016, Vision Kino. Bonn: Netzwerk für Film und Medienkompetenz \& Bundeszentrale für politische Bildung, 3-4.

Hensel-Grobe, Meike (2017): Problemorientierung und problemlösendes Denken. In: Barricelli, Michele \& Lücke, Martin (Eds.): Praxis des Geschichtsunterrichts 2. Wiesbaden: Wochenschau Verlag, 50-63.

Jordan, Stefan (2010): Theorien und Methoden der Geschichtswissenschaft. Orientierung Geschichte. Paderborn: Ferdinand Schöningh.

KMK - Kultusministerkonferenz (2018): Demokratie als Ziel, Gegenstand und Praxis historisch-politischer Bildung und Erziehung in der Schule, Beschluss der Kultusministerkonferenz vom 06.03.2009, in der Fassung vom 11.10.2018.

Köster, Juliane (2016): Aufgaben im Deutschunterricht. Wirksame Lernangebote und Erfolgskontrollen. Seelze: Klett Verlag.

Lücke, Martin (2017): Multiperspektivität. Kontroversität, Pluralität. In: Barricelli, Michele \& Lücke, Martin (Eds.): Praxis des Geschichtsunterrichts 1. Wiesbaden: Wochenschau Verlag, 281-288.

Moegling, Klaus (2010): Kompetenzaufbau im fächerübergreifenden Unterricht Förderung vernetzten Denkens und komplexen Handelns. Immenhausen: Prolog-Verlag. 
Mounajed, René (2017): „Holocaust Education“ und Menschenrechtserziehung im Geschichtsunterricht. In: Barricelli, Michele \& Lücke, Martin (Eds.): Praxis des Geschichtsunterrichts 2. Wiesbaden: Wochenschau Verlag, 263-289.

Overwien, Bernd (2020): Politische Bildung: Teil der Allgemeinbildung. In: Albrecht, Achim, Bade, Gesine, Eis, Andreas, Jakubczyk, Uwe \& Overwien, Bernd (Eds.): Jetzt erst recht: Politische Bildung! Bestandsaufnahme und bildungspolitische Forderungen. Frankfurt (Main): Wochenschau Verlag, 87-97.

Petrik, Andreas (2016): Rollenspiel. In: Reinhardt, Sibylle \& Richter, Dagmar (Eds.): Politik. Methodik. Handbuch für die Sekundarstufe I und II. Berlin: Cornelsen, 116-122.

Pressler, Miriam (2013): Anne Frank Tagebuch - Editorische Notiz. In: Anne Frank: Gesamtausgabe. Bonn: Bundeszentrale für politische Bildung, 11-13.

Rosenbrock, Cornelia \& Nix, Daniel (2017): Grundlagen der Lesedidaktik und der systematischen schulischen Leseförderung. Hohengehren: Schneider Verlag.

Scholz, Ingvelde (2014): Diagnose und Förderung. In: Bovert, Gislinde \& Huwendiek, Volker (Eds.): Leitfaden Schuplpädagogik. Pädagogik und Psychologie für den Lehrerberuf. Berlin: Cornelsen, 304-348.

Schulze, Winfried (1996): Ego-Dokumente. Annäherung an den Menschen in der Geschichte? Berlin: Akademie Verlag.

Schultz, Sonja M. (2012): Der Nationalismus im Film. Von TRIUMPF DES WILLENS bis INGLOURIOUS BASTERDS. Berlin: Bertz + Fischer Verlag.

Siems, Marion (2003): Anne Frank. Tagebuch. Erläuterungen und Dokumente. Stuttgart: Reclam.

Spinner, Kaspar H. (2001): Literaturunterricht und moralische Entwicklung. In: Spinner, Kaspar H. (Ed.): Kreativer Deutschunterricht. Identität - Imagination Kognition. Seelze: Kallmeyer, 73-88.

Spinner, Kaspar H. (2006): Literarisches Lernen. In: Praxis Deutsch 200/2006, 6-16.

Spinner, Kaspar H. (2011): Handlungs- und produktionsorientierte Verfahren im Literaturunterricht. In: Kämper-van den Boogart, Michael (Ed.): Deutsch-Didaktik. Leitfaden für die Sekundarstufe I und II. Berlin: Cornelsen, 184-198.

Thünemann, Holger (2013): Historische Lernaufgaben. Theoretische Überlegungen, empirische Befunde und forschungspragmatische Perspektiven. In: Zeitschrift für Geschichtsdidaktik, September 2013, 141-155.

Ulrich, Michaela \& Ulrich, Dieter (1994): Literarische Sozialisation. Wie kann das Lesen von Geschichten zur Persönlichkeitsentwicklung beitragen? In: Zeitschrift für Pädagogik 4 (5), 821-834.

Wrobel, Dieter \& von Brand, Tilman (2012): Nationalsozialismus. Basisartikel. In: Praxis Deutsch, № 236, 4-11.

Zühlsdorf-Kersting, Meik (2007): Sechzig Jahre danach. Jugendliche und Holocaust. Eine Studie zur geschichtskulturellen Sozialisation. Berlin: Lit. Verlag. 
